\section{Effect of treatment with sitagliptin on somatosensory-evoked potentials and metabolic control in patients with type 2 diabetes mellitus}

\author{
Efeito do tratamento com sitagliptina sobre os potenciais \\ evocados somatossensoriais e controle metabólico \\ de pacientes com diabetes melito tipo 2
}

Joelma Ines Tagliapietra Barros', Francisco Vagnaldo Fechine', Renan Magalhães Montenegro Júnior' ${ }^{2}$, Otoni Cardoso do Vale ${ }^{3}$, Virgínia Oliveira Fernandes ${ }^{4}$, Marcellus Henrique Loiola Ponte de Souza $^{5}$, Gilmara Holanda da Cunha', Manoel Odorico de Moraes', Catarina Brasil d'Alva', Maria Elisabete Amaral de Moraes'

\begin{abstract}
Objective: To evaluate the effect of sitagliptin on somatosensory-evoked potentials (SEPs) and metabolic control in patients with type 2 diabetes mellitus without clinical diabetic neuropathy. Materials and methods: Interventional, prospective, and open study. Patients with less than six months from the diagnosis were included. Examinations of SEPs and laboratory tests at fasting and after food stimulation were performed before and after three months of treatment with sitagliptin (100 mg/day). Results: There was a reduction in the mean levels of $\mathrm{HbA} 1 \mathrm{c}(\mathrm{P}<$ $0.0001)$, fasting glucose $(P=0.001)$, total cholesterol $(P=0.019)$, and ALT $(P=0.022)$. An increase in active GLP-1 was found at the end of the study $(P=0.0025)$. Several SEPs showed statistically significant differences when analyzed before and after treatment with sitagliptin. Conclusion: The results give a glimpse of the possible use of sitagliptin in the treatment of some neurodegenerative conditions of the peripheral nervous system, in addition to its already established role in glycemic control. Arq Bras Endocrinol Metab. 2014;58(4):369-76
\end{abstract}

Keywords

Diabetes mellitus, type 2; dipeptidyl-peptidase IV inhibitors; incretins; diabetes complications

\section{RESUMO}

Objetivo: Avaliar o efeito da sitagliptina nos potenciais evocados somatossensoriais (PESS) e controle metabólico de pacientes com diabetes melito tipo 2, sem neuropatia diabética. Materiais e métodos: Estudo de intervenção, prospectivo e aberto. Os pacientes com menos de seis meses de diagnóstico foram incluídos. Exames dos PESS e testes laboratoriais em jejum e após a estimulação com alimentos foram realizados antes e depois de três meses de tratamento com sitagliptina (100 mg/dia). Resultados: Houve redução nos níveis médios de $\mathrm{HbA1c}(\mathrm{P}<0,0001)$, glicemia de jejum $(P=0,001)$, colesterol total $(P=0,019)$ e ALT $(P=0,022)$. Verificou-se aumento de GLP-1 ativo ( $P=0,0025)$. Vários PESS mostraram diferenças estatisticamente significativas quando os valores foram analisados antes e após o tratamento com sitagliptina. Conclusão: Os resultados vislumbram a possível utilização de sitagliptina no tratamento de algumas condições neurodegenerativas do sistema nervoso periférico, em adição ao seu papel no controle glicêmico. Arq Bras Endocrinol Metab. 2014;58(4):369-76

\section{Descritores}

Diabetes melito tipo 2; inibidores da dipeptidil-peptidase IV; incretinas; complicações do diabetes
' Clinical Pharmacology Unit, Department of Physiology and Pharmacology, School of Medicine, Universidade Federal do Ceará (UFC), Fortaleza, CE, Brazil ${ }^{2}$ Department of Community Health, School of Medicine, UFC, Fortaleza, CE, Brazil ${ }^{3}$ Department of Clinical Medicine, School of Medicine, UFC, Fortaleza, CE, Brazil ${ }^{4}$ University Hospital Walter Cantidio, UFC, Fortaleza, CE, Brazil ${ }^{5}$ Department of Physiology and Pharmacology, School of Medicine, UFC, Fortaleza, CE, Brazil ${ }^{6}$ Department of Nursing, UFC, Fortaleza, CE, Brazil

Correspondence to: Maria Elisabete Amaral de Moraes Clinical Pharmacology Unit, Department of Physiology and Pharmacology,

Faculdade de Medicina Universidade Federal do Ceará Coronel Nunes de Melo, 1127 Rodolfo Teófilo

60430-270 - Fortaleza, CE, Brazil gpclinica@unifac.med.br

Received on Ago/2/2013 Accepted on Jan/24/2014

DOI: 10.1590/0004-2730000002914 


\section{INTRODUCTION}

D

iabetes mellitus, a chronic non-transmissible disease, is one of the most prevalent diseases in the world (1). Hyperglycemia increases inflammation, osmotic damage and neuronal oxidative stress, leading to impaired function of proteins and damage to transcription factors and mitochondrial DNA, as well as increasing the expression of pro-apoptotic proteins. These interconnected processes are harmful to the nervous system, slowing axonal transport by altering neuronal signaling, and ultimately promoting neuronal dysfunction (2).

Diabetic neuropathy is defined as the presence of signs or symptoms of peripheral nerve dysfunction in diabetic patients after the exclusion of other causes (3). Deficiencies in central nervous system conduction in diabetics can be readily detected by the study of somatosensory-evoked potentials (SEPs), which are the electrical responses of the nervous system to motor or sensory stimulation. Its role in the diagnosis of neurological diseases is the identification or location of one or more lesions in somatosensory pathways, even before the onset of clinical abnormalities (4). Glycemic control improves nerve conduction. Studies with glucagon-like peptide-1 (GLP-1) analogues and dipeptidyl peptidase-4 (DPP-4) inhibitors show that, in addition to its hypoglycemic effect, they may act directly on nerve cell protection against lipotoxicity and glucotoxicity $(5-8)$.

In this context, sitagliptin binds to DPP-4 and prevents the breakdown of GLP-1 and glucose-dependent insulinotropic polypeptide (GIP). Both GLP-1 and GIP are types of incretin hormones released by the intestines, which stimulate insulin secretion from $\beta$ cells and suppress glucagon secretion. GLP-1 and GIP are rapidly broken down by DPP-4. Incretin hormones depend on the level of blood glucose to stimulate insulin. DPP-4 inhibitors are associated with lower incidence of hypoglycemia compared with conventional hypoglycemic drugs (9).

Thus, this study aimed to evaluate the effects of treatment with sitagliptin on SEPs and metabolic control (as well as their interrelationships) in patients with type 2 diabetes mellitus without clinical diabetic neuropathy.

\section{MATERIALS AND METHODS}

\section{Patients}

This study was conducted in accordance with the Declaration of Helsinki, and the protocol was approved by the
Ethics Committee of the Federal University of Ceará, in Fortaleza, Brazil, under registration number 189/07. All patients gave their written, informed consent and were free to withdraw from the trial at any time.

Twenty type 2 diabetic patients aged 18-65 years were eligible and agreed to take part in the study. Eligible patients were those newly diagnosed (less than six months), not previously treated with hypoglycemic drugs or in wash-out period of seven half-lives of the hypoglycemic drug used before entering the study, and without clinical diabetic neuropathy. The exclusion criteria were positive ketones in the urine (ketonuria) above two plus $(2+)$, any symptoms or signs suggestive of brain or neurological involvement, insulin use, pregnant or nursing women, history of alcohol intake greater than or equal to $20 \mathrm{~g} /$ day.

\section{Study design}

Patients were evaluated in the pre-treatment period, monthly during the three months of treatment, and in the post-treatment period. In the pre- and post-treatment periods, the patients were examined and blood pressure was measured after sitting for at least $15 \mathrm{~min}$ using a calibrated electronic sphygmomanometer, and using the average of two readings. Blood was drawn (12 hours fasting) for complete blood count, glycated hemoglobin (HbAlc) (turbidimetry), insulin, glucagon (radioimmunoassay), active GLP-1 (immunoassay), glucose, total cholesterol, HDL cholesterol, triglycerides, alanine aminotransferase (ALT), aspartate aminotransferase (AST), and gamma glutamyl transferase (GGT) (automated enzymatic method). The meal test consisted in the ingestion of a 566-kcal shake $(33 \%$ lipids, $20 \%$ protein and $47 \%$ carbohydrate of slow absorption), followed by the collection of blood samples at $5,15,30,45,60,90,120,150$, and 180 minutes, to perform serial measurements of glucose, insulin, glucagon, and active GLP-1. The values obtained were used to calculate the area under the curve for glucose, insulin, glucagon, and active GLP-1.

For the 15-minute-fast collection, i.e., the first collection 15 minutes before food stimulation, tubes were prepared with EDTA anticoagulant for complete blood count, anticoagulant with fluoride for glucose, and without anticoagulant for the other biochemical tests. For determination of active GLP-1, a tube with EDTA anticoagulant was used added of DPP IV inhibitor (diprotin $-10 \mu \mathrm{L} / \mathrm{mL}$ of blood) at the time of collection. 
After that, this tube was immediately placed on ice to prevent peptide breakdown. For glucagon determination, the blood sample was collected in a tube without anticoagulant but added of a protease inhibitor cocktail (20 $\mu \mathrm{L} / \mathrm{mL}$ blood). Then, it was immediately placed in an ice bath. For the other times $(0$ minute of fasting and $5,15,30,45,60,90,120,150$, and 180 minutes after food intake), samples were collected only for glucose, insulin, glucagon, and active GLP-1.

Patients were then submitted to the examination of SEPs. The patient was kept in a supine position, alert or in spontaneous sleep without sedatives in a quiet room. Square pulses of 0.2 milliseconds duration were applied on the median nerve in the wrist, at a frequency of three pulses per second. Surface electrodes (coated with silver chloride, measuring $\mathrm{l} \mathrm{cm}$ in diameter) were affixed to the skin, previously cleaned, covered with colloid conductive paste in five regions, including Erb's point (the angle between the sternocleidomastoid muscle and the clavicle) ipsilateral to the stimulus (N9), spinous process of the sixth cervical vertebra (VC6), anterior neck above the thyroid cartilage (PA), the parietal region $70 \mathrm{~mm}$ lateral to midline and $30 \mathrm{~mm}$ behind $\mathrm{Cz}$ (midpoint of the midline), subsequent to the region contralateral to the stimulus of potential $\mathrm{N} 9$ and $\mathrm{N} 20$ (N20 records the activity of the cerebral cortex), and frontal median (Fz reference electrode). The ground electrode for the five regions was affixed on the shoulder contralateral to the stimulus. We evaluated the peak latencies of the following potentials: Erb (N9), spinal (N13) in assembly VC6-PA and potentials $\mathrm{N} 20$ picked up by electrodes on the scalp.

The conduction time from component $\mathrm{N} 9$ to spinal component $\mathrm{Nl} 3$ or spinal $\mathrm{Nl} 3$ response component to $\mathrm{N} 20$ cortical potential and of potential $\mathrm{N} 9$ to potential N20 was measured by the peak-to-peak method. The peak latency of the spinal N13 potential in the assembly VC6-PA was taken as the entry time of the nerve impulse in the spinal cord (10). The peak latency of component N20 (cortical arrival time) was identified as a marker where the frontal and parietal contralateral potentials diverge. The central conduction time (CCT) was defined as the transit time between the peak of the N9-N13, N13-N20, and N9-N20 potential.

After this assessment, patients were instructed to take a tablet of $100 \mathrm{mg}$ sitagliptin once daily in the morning, while fasting, for three months. They were assessed monthly by a physician, and they were excluded from the study if it was necessary to introduce other hypoglycemic agents or insulin. After three months, the patients underwent laboratory and electrophysiological tests again, and were reassessed by a physician.

\section{Statistical analysis}

The quantitative variables were initially analyzed by the Kolmogorov-Smirnov test to verify the normality of distribution. Descriptive statistics were expressed as the means and standard deviations. Comparisons between pre- and post-treatment were made using the paired $t$ test. The degree and sign of linear correlation between two variables were quantified by the Pearson's correlation coefficient. Areas under the curve (AUCs) were calculated using the trapezoidal rule and compared using the $t$ test for paired data $(11,12)$.

In all cases, probability $\alpha$ of type I error (significance level) was set at $0.05(5 \%)$, which was considered statistically significant $(\mathrm{P}<0.05)$. The software GraphPad Prism ${ }^{\circledR}$ version 5.00 for Windows ${ }^{\circledR}$ (GraphPad Software, San Diego, California, USA, 2007) was used to perform the statistical procedures and to prepare the graphs.

\section{RESULTS}

Of the 20 patients evaluated, 14 were female and six were male, and the average age was $53.2 \pm 8.4$ years without statistically significant difference in age between the sexes $($ males $=55.0 \pm 6.4$ years and females $=$ $51.3 \pm 10.3$ years; $\mathrm{P}=0.42$ ).

There was a reduction in the mean levels of HbAlc (pre-treatment: $8.17 \pm 1.90 \%$; post-treatment: $6.66 \pm$ $1.27 \% ; \mathrm{P}<0.0001$ ), fasting glucose (pre-treatment: $169.32 \pm 53.72 \mathrm{mg} / \mathrm{dL}$; post-treatment: $136.42 \pm$ $29.68 \mathrm{mg} / \mathrm{dL} ; \mathrm{P}=0.001$ ), total cholesterol (pre-treatment: $209.40 \pm 48.90 \mathrm{mg} / \mathrm{dL}$; post-treatment: 189.65 $\pm 28.19 \mathrm{mg} / \mathrm{dL} ; \mathrm{P}=0.019$ ) and ALT (pre-treatment: $24.83 \pm 13.78 \mathrm{U} / \mathrm{L}$; post-treatment: $20.85 \pm 13.94$ $\mathrm{U} / \mathrm{L} ; \mathrm{P}=0.022$ ). An increase in active GLP-1 was observed at the end of the study (pre-treatment: $7.86 \pm$ $3.78 \mathrm{pmol} / \mathrm{L}$; post-treatment: $14.16 \pm 10.18 \mathrm{pmol} / \mathrm{L}$; $\mathrm{P}=0.0025)$ (Table 1$)$.

An analysis of the AUCs (test meal) showed significant reductions in the concentrations of glucose and glucagon (Figure 1) after treatment with sitagliptin $(\mathrm{P}=0.0001$ and $\mathrm{P}=0.0021$, respectively). Active GLP$\mathrm{l}$, in its turn, increased significantly after treatment $(\mathrm{P}$ $=0.003)$, and there was no statistically significant increase in insulin AUC after treatment $(\mathrm{P}=0.1045)$ (Figure 2). 
Table 1. Comparison of biochemical variables in the pre- and post-treatment with sitagliptin. Data expressed as means \pm standard deviations

\begin{tabular}{|c|c|c|c|c|c|}
\hline Parameter & Pre-treatment & Post-treatment & $\begin{array}{l}\text { Difference between } \\
\text { means (Cl-95\%) }\end{array}$ & $P$ value & Reference range \\
\hline Glucose & $169.32 \pm 53.72$ & $136.42 \pm 29.68$ & $34.41(15.20-50.59)$ & 0.001 & $70-99$ mg/dL \\
\hline $\mathrm{HbA1c}$ & $8.17 \pm 1.90$ & $6.66 \pm 1.27$ & $1.51(0.91-2.11)$ & $<0.0001$ & $<6 \%$ \\
\hline Insulin & $18.09 \pm 11.90$ & $20.57 \pm 12.47$ & $-2.48(-7.07-2.11)$ & 0.273 & $0-30 \mu \mathrm{Ul} / \mathrm{mL}$ \\
\hline Glucagon & $62.40 \pm 20.12$ & $53.73 \pm 17.92$ & $4.70(1.26-10.59)$ & 0.120 & $<60 \mathrm{pg} / \mathrm{mL}$ \\
\hline Active GLP1 & $7.86 \pm 3.78$ & $14.16 \pm 10.18$ & $-6.30(-10.09--2.52)$ & 0.0025 & $5-10 \mathrm{pmol} / \mathrm{L}$ \\
\hline Triglycerides & $230.25 \pm 194.63$ & $178.95 \pm 70.06$ & $51.30(-27.80-130.40)$ & 0.190 & $<150 \mathrm{mg} / \mathrm{dL}$ \\
\hline Total cholesterol & $209.40 \pm 48.90$ & $189.65 \pm 28.19$ & $19.75(3.56-35.94)$ & 0.019 & $<200 \mathrm{mg} / \mathrm{dL}$ \\
\hline HDL cholesterol & $40.15 \pm 9.10$ & $39.40 \pm 10.14$ & $0.75(-1.77-3.27)$ & 0.540 & $\geq 60 \mathrm{mg} / \mathrm{dL}$ \\
\hline LDL cholesterol & $123.20 \pm 36.81$ & $114.46 \pm 21.59$ & $8.74(-5.57-23.05)$ & 0.222 & $<100 \mathrm{mg} / \mathrm{dL}$ \\
\hline GGT & $33.37 \pm 21.81$ & $27.06 \pm 12.27$ & $6.31(-0.28-12.90)$ & 0.059 & $\begin{array}{l}\text { Male: } 8-61 \mathrm{U} / \mathrm{L} \\
\text { Female: } 5-36 \mathrm{U} / \mathrm{L}\end{array}$ \\
\hline AST & $20.46 \pm 8.64$ & $18.87 \pm 10.09$ & $1.59(-0.65-3.84)$ & 0.154 & $\begin{array}{c}\text { Male: } \leq 38 \mathrm{U} / \mathrm{L} \\
\text { Female: } \leq 32 \mathrm{U} / \mathrm{L}\end{array}$ \\
\hline ALT & $24.83 \pm 13.78$ & $20.85 \pm 13.94$ & $3.98(0.62-7.32)$ & 0.022 & $\begin{array}{c}\text { Male: } \leq 41 \mathrm{U} / \mathrm{L} \\
\text { Female: } \leq 31 \mathrm{U} / \mathrm{L}\end{array}$ \\
\hline
\end{tabular}

Cl-95\%: 95\% confidence interval; P value: statistical significance; HbA1c: glycated hemoglobin; HDL: high density lipoprotein; GGT: gamma glutamyl transferase; AST: aspartate aminotransferase; ALT: alanine aminotransferase.
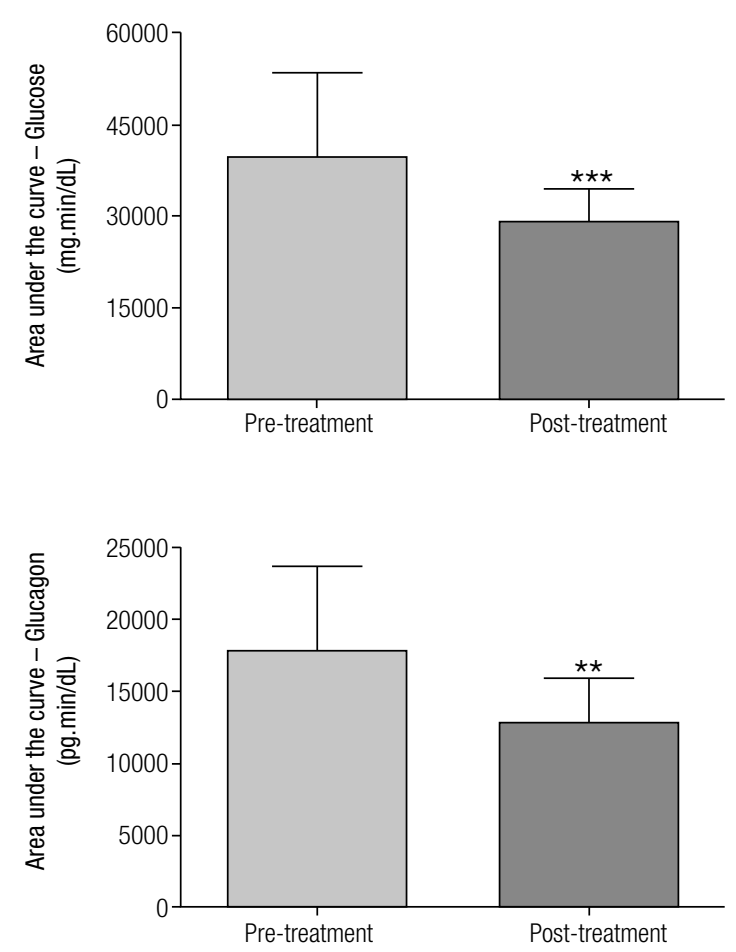

Figure 1. Area under the curve of glucose and glucagon in the meal test before (pre-treatment) and three months after treatment with sitagliptin (post-treatment). Data expressed as means and standard deviations. ${ }^{\star \star *} P=0.0001 ;{ }^{* \star} P=0.0021$
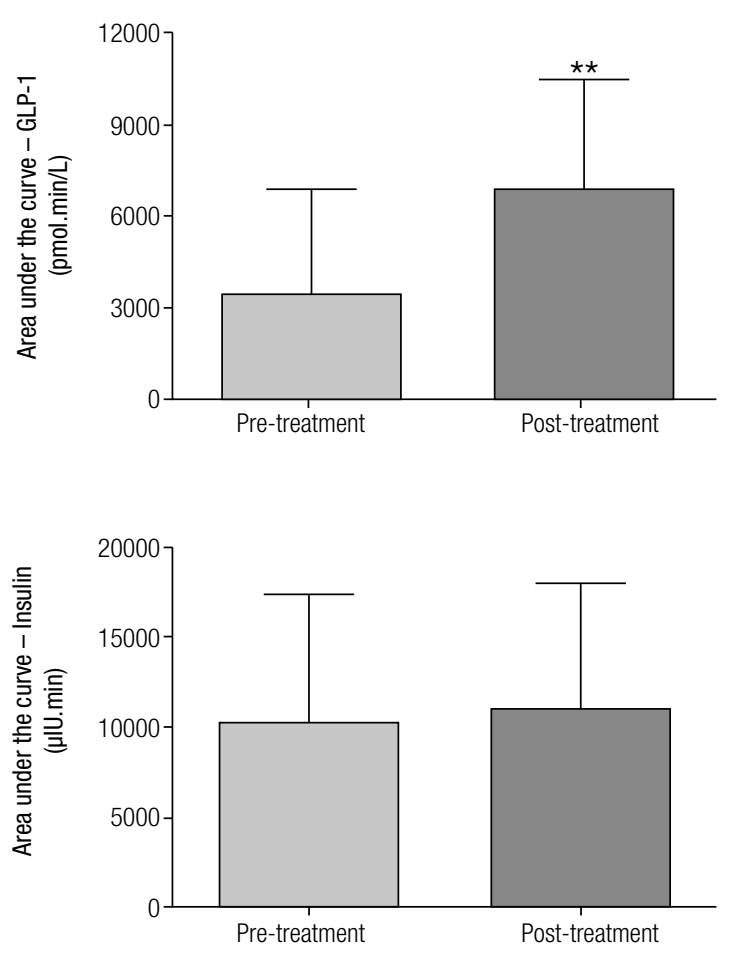

Figure 2. Area under the curve of active GLP-1 and insulin in the meal test before (pre-treatment) and three months after treatment with sitagliptin (post-treatment). Data expressed as means and standard deviations. ${ }^{\star \star} P=0.0030$. 
No statistically significant differences were observed in the amplitude of evoked potentials when patients were divided into low and high potential, using the median $(153.5 \mathrm{~cm})$ as the cutoff value, either before or after treatment with sitagliptin. Before treatment with sitagliptin, nerve conduction displayed abnormalities even without clinical symptoms, compared with the reference values of the laboratory where the tests were performed. As seen in table 2, several evoked potentials showed statistically significant differences when values were analyzed before and after treatment with sitagliptin.

Significant correlations were observed for changes in some measurements of SEPs, and in the changes of some biochemical parameters after treatment with sitagliptin. There was a positive correlation $(r=0.48$, $\mathrm{P}=0.04$ ) between the change in fasting glucose concentration and the variation in Nl3 R latency in that the decrease in fasting glucose concentration was associated with a reduction in the latency of the evoked potential N13 on the right side at the end of treatment with sitagliptin. For this same potential, we observed a trend toward a positive correlation with $\mathrm{HbAlc}(\mathrm{P}=$ $0.07)$. There was also a positive correlation $(\mathrm{r}=0.53$, $\mathrm{P}=0.03$ ) between the change in fasting glucagon and
N13 latency evoked from the left side, indicating that a decrease in fasting glucagon concentration was associated with a decrease in latency of $\mathrm{Nl} 3$ on the left side after treatment with sitagliptin. Regarding the area under the curve of active GLP-1, we observed a negative correlation $(\mathrm{r}=-0.62, \mathrm{P}=0.02)$ with the variation in latency of N20 L, i.e., an increase in GLP-1 AUC correlated with a reduction in latency of N20 left at the end of treatment with sitagliptin (Table 3 ).

Importantly, among the parameters measured at fasting, the variation in triglyceride levels had a negative correlation $(\mathrm{r}=-0.47, \mathrm{P}=0.03)$ with the variation in AUC of active GLP-l after treatment with sitagliptin, i.e., the decrease in fasting triglyceride concentration was correlated with an increase in concentration of active GLP-1 after food stimulation.

In the analysis of central conduction times (CCT), the AUC of active GLP-1 was negatively correlated with the central conduction time N9 - N20L $(\mathrm{r}=-0.57$, $\mathrm{P}=0.04)$ and the central conduction time N13-N20L $(\mathrm{r}=-0.60, \mathrm{P}=0.03)$. This finding indicates that an increase in AUC of active GLP-1 after sitagliptin treatment is correlated with a decrease in central conduction time N9-N20 and N13-N20 on the left side (Table 4).

Table 2. Comparison of latency and conduction times of somatosensory-evoked potentials (SEPS) in the pre- and post-treatment with sitagliptin

\begin{tabular}{|c|c|c|c|c|c|}
\hline Variable & Laboratory RV & $\begin{array}{c}\text { Pre-treatment } \\
\text { Mean } \pm \text { SD }\end{array}$ & $\begin{array}{l}\text { Post-treatment } \\
\text { Mean } \pm \text { SD }\end{array}$ & $\begin{array}{c}\text { DIF } \\
\text { (CI-95\%) }\end{array}$ & $P$ value \\
\hline Latency N9 R (ms) & $9.77 \pm 0.78$ & $10.105 \pm 1.07$ & $9.81 \pm 0.88$ & $0.30(0.17-0.42)$ & $<0.0001$ \\
\hline Latency N9 L (ms) & $9.77 \pm 0.78$ & $9.84 \pm 1.05$ & $9.82 \pm 1.03$ & $0.02(-0.17-0.23)$ & 0.774 \\
\hline Latency N13 R (ms) & $12.73 \pm 1.01$ & $13.32 \pm 1.40$ & $13.20 \pm 1.40$ & $0.12(-0.18-0.40)$ & 0.455 \\
\hline Latency N13 L (ms) & $12.73 \pm 1.01$ & $13.09 \pm 1.25$ & $12.73 \pm 1.21$ & $0.36(0.027-0.68)$ & 0.036 \\
\hline Latency N20 R (ms) & $18.99 \pm 1.93$ & $19.34 \pm 1.57$ & $18.68 \pm 2.02$ & $0.66(0.080-1.24)$ & 0.028 \\
\hline Latency N20 L (ms) & $18.99 \pm 1.93$ & $19.58 \pm 1.49$ & $18.86 \pm 1.51$ & $0.72(-0.32-1.76)$ & 0.160 \\
\hline $\begin{array}{l}\text { Conduction time } \\
\text { N9 - N13 R (ms) }\end{array}$ & $2.96 \pm 0.50$ & $3.23 \pm 0.58$ & $3.44 \pm 0.60$ & $-0.21(-0.54-0.13)$ & 0.214 \\
\hline $\begin{array}{ll}\text { Conduction } & \text { time } \\
\mathrm{N} 9-\mathrm{N} 13 \mathrm{~L}(\mathrm{~ms}) & \end{array}$ & $2.96 \pm 0.50$ & $3.33 \pm 0.45$ & $2.93 \pm 0.53$ & $0.40(0.008-0.71)$ & 0.045 \\
\hline $\begin{array}{l}\text { Conduction time } \\
\text { N9 - N20 R (ms) }\end{array}$ & $9.21 \pm 1.64$ & $9.22 \pm 0.78$ & $8.86 \pm 1.40$ & $0.36(-0.20-0.93)$ & 0.191 \\
\hline $\begin{array}{l}\text { Conduction time } \\
\mathrm{N} 9 \text { - N20 L (ms) }\end{array}$ & $9.21 \pm 1.64$ & $9.66 \pm 1.34$ & $8.95 \pm 1.17$ & $0.71(-0.40-1.83)$ & 0.190 \\
\hline $\begin{array}{l}\text { Conduction time } \\
\text { N13 - N20 R (ms) }\end{array}$ & $6.26 \pm 1.62$ & $5.96 \pm 0.89$ & $5.31 \pm 1.22$ & $0.65(0.021-1,28)$ & 0.044 \\
\hline $\begin{array}{l}\text { Conduction time } \\
\text { N13 - N20 L (ms) }\end{array}$ & $6.26 \pm 1.62$ & $6.33 \pm 1.46$ & $6.04 \pm 0.95$ & $0.29(-0.70-1.28)$ & 0.530 \\
\hline
\end{tabular}

RV: reference value; SD: standard deviation; DIF: difference between means; Cl-95\%: confidence interval of 95\%; ms: millisecond; R: right; L: left. 
Table 3. Correlation between the changes in the latency of SEPS and changes in some biochemical parameters measured at fasting and after food stimulation before and after the treatment with sitagliptin

\begin{tabular}{|c|c|c|c|c|c|c|c|}
\hline \multirow{2}{*}{ Variable } & \multirow{2}{*}{ Correlation } & \multicolumn{6}{|c|}{ Latency } \\
\hline & & N9R & N9L & N13R & N13L & N20R & N2OL \\
\hline \multirow[t]{2}{*}{$\mathrm{HbA1c}$} & $r$ & -0.06 & 0.36 & 0.43 & 0.08 & -0.15 & 0.21 \\
\hline & $P$ & 0.81 & 0.142 & 0.07 & 0.74 & 0.54 & 0.47 \\
\hline \multirow[t]{2}{*}{ Fasting glucose } & r & 0.13 & 0.25 & 0.48 & 0.23 & 0.23 & 0.53 \\
\hline & $P$ & 0.59 & 0.31 & 0.04 & 0.37 & 0.36 & 0.06 \\
\hline \multirow[t]{2}{*}{ Fasting glucagon } & r & 0.17 & 0.134 & -0.02 & 0.53 & 0.17 & -0.10 \\
\hline & $P$ & 0.49 & 0.60 & 0.93 & 0.03 & 0.50 & 0.74 \\
\hline \multirow[t]{2}{*}{ AUC active GLP-1 } & r & 0.24 & 0.19 & 0.20 & 0.14 & -0.31 & -0.62 \\
\hline & $P$ & 0.30 & 0.45 & 0.43 & 0.56 & 0.22 & 0.02 \\
\hline \multirow[t]{2}{*}{ AUC glucose } & $r$ & 0.002 & 0.33 & 0.46 & 0.26 & -0.11 & 0.50 \\
\hline & $P$ & 0.99 & 0.19 & 0.06 & 0.28 & 0.67 & 0.07 \\
\hline
\end{tabular}

N9 R: latency N9 right; N9 L: latency N9 left; N13 R: latency N13 right; N 13L: latency N13 left; N20 R: latency N20 right; N20 L: latency N20 left; HbA1c: glycated hemoglobin; GLP-1: glucagon-like peptide-1; r: Pearson correlation coefficient; P: statistical significance of the correlations.

Table 4. Correlation between changes in central conduction time (CCT) of SEPs and changes in some biochemical parameters measured in the fasting state before and after treatment with sitagliptin

\begin{tabular}{|c|c|c|c|c|c|c|c|}
\hline \multirow{2}{*}{ Variables } & \multirow{2}{*}{ Correlation } & \multicolumn{6}{|c|}{ Central conduction time } \\
\hline & & N9-N13 R & N9-N13 L & N9-N20 R & N9-N20 L & N13-N20 R & N13-N20 L \\
\hline \multirow[t]{2}{*}{ HbA1c } & $r$ & 0.41 & -0.12 & -0.13 & 0.12 & -0.38 & 0.257 \\
\hline & $P$ & 0.09 & 0.64 & 0.64 & 0.69 & 0.132 & 0.40 \\
\hline \multirow[t]{2}{*}{ Fasting glucose } & r & 0.37 & 0.09 & 0.201 & 0.45 & -0.03 & 0.51 \\
\hline & $P$ & 0.13 & 0.72 & 0.42 & 0.126 & 0.90 & 0.07 \\
\hline \multirow[t]{2}{*}{ Triglycerides } & $r$ & 0.03 & 0.03 & 0.33 & 0.50 & 0.29 & 0.40 \\
\hline & $P$ & 0.92 & 0.90 & 0.21 & 0.08 & 0.257 & 0.17 \\
\hline \multirow[t]{2}{*}{ AUC Active GLP-1 } & r & 0.07 & 0.24 & -0.33 & -0.57 & -0.27 & -0.60 \\
\hline & $P$ & 0.77 & 0.36 & 0.21 & 0.04 & 0.29 & 0.03 \\
\hline
\end{tabular}

R: right; L: left; AUC: area under the curve; HbA1c: glycated hemoglobin; GLP-1: glucagon-like peptide-1; r: Pearson correlation coefficient; P: statistical significance of the correlations.

\section{DISCUSSION}

This study evaluated the effects of sitagliptin on SEPs and metabolic control of patients with type 2 diabetes mellitus without clinical diabetic neuropathy. Fasting blood glucose levels decreased after treatment, as well as the concentration of HbAlc. In this study, mean concentration of HbAlc after treatment was $6.66 \%$, and over $75 \%$ had a satisfactory result in relation to the reduction of HbAlc. It is likely that this result reflects the short duration of disease in these patients, who still have a good supply of functioning $\beta$ cells and are, therefore, more responsive to treatment.

Regarding active GLP-1, the AUC was lower before treatment, and there was a substantial increase after the use of DPP-4 inhibitor, as described in previous studies $(13,14)$. Before treatment, the patients had abnormali- ties in nerve transmissions even without clinical symptoms. Several electrophysiological studies have documented increased latencies in addition to the slowing of nerve conduction in diabetic patients compared with normal subjects, suggesting lesions in the somatosensory nerve pathways (15-17).

After treatment with sitagliptin, there was an improvement in nerve impulse conduction. Conducting pathways rostral to the bulb (medial lemniscus and thalamocortical) showed greater improvement when the right median nerve was stimulated, and there was also a significant decrease in latency of $\mathrm{N} 20$ and central conduction time N13-N20. A significant reduction was also observed in evoked potential latency $\mathrm{N} 9$ on the right side, indicating the effect of treatment also on the conduction of peripheral nerve pathways on this side. 
Furthermore, when the left median nerve was stimulated, it was found that the effects of treatment were most intense in the proximal peripheral conduction or root, since there was a significant reduction in latency of N13 and of central conduction time N9-N13. The short treatment period, as well as the small number of volunteers who participated in the study $(\mathrm{n}=20)$, may have contributed to the asymmetric improvement of nerve conduction.

The triggering factor of most complications in diabetes is chronic exposure to high glucose levels (18). In our study, an analysis of the correlation between the electrophysiological and biochemical parameters showed that improvement of glycemic control observed in the three months of treatment was associated with improved measures of some evoked potentials. Electrophysiological studies in type 1 and 2 diabetes with short disease duration and without clinical complications have found significant abnormalities in latency values of visual and auditory SEPs, and these abnormalities were correlated with the state of glycemic control (19). Other study also found significant correlations between changes in SEPs, HbAlc and fasting glucose (16).

On the other hand, studies of the effects of recombinant GLP-1 in rats demonstrated a reduction in intestinal lymph flow, triglyceride absorption and synthesis of apolipoproteins, which limited the release of triglycerides into the circulation after providing feed containing lipids. In our study, we observed that the increase in area under the curve of active GLP-1 was correlated with decreased serum triglyceride levels after treatment. Moreover, the decrease in triglycerides correlated with the improvement in conduction time N9-N20L (20).

Studies have shown a significant association of triglyceride levels with changes in SEPs (16), and elevated triglyceride levels have been correlated with the loss of myelinated fibers in the sural nerve (21). Studies examining the action of GLP-1 and exendin-4 on proliferation, differentiation and neuronal degeneration of nerve cells (6-8), and the effect of the DPP-4 inhibitor vildagliptin on peripheral nerves of streptozotocininduced diabetic rats (9) suggested that the DPP-4 inhibitor can prevent the degeneration of peripheral nerves in an animal model of induced diabetes.

In line with the literature reviewed, we noted that increased concentration of active GLP-1 caused by the treatment with the inhibitor of the enzyme that degrades the endogenous peptide was correlated with improvement in nerve impulse conduction. Taking into account the correlations between the results of evoked potentials, metabolic control and active GLP-1 levels, the question now is whether improved nerve conduction in these patients was due to a direct neuroprotective/neuroregenerative effect of endogenous GLP-1 caused by binding to its receptors on peripheral and central nerves, a direct consequence of metabolic control achieved with the therapy, or both.

In this study, sitagliptin produced about two times greater concentration of endogenous GLP-1. It is speculated that its use for a longer period, or the use of GLP-1 analogues that increase GLP-1 levels over ten times could show better improvement in the conduction of nerve impulses. Preclinical studies suggest the possibility that activation of GLP-1 receptor may have a neuroprotective/neuroregenerative effect by means of mechanisms independent of glycemic control (22-25).

In reviewing the literature, no studies similar to ours were found. Based on the results of preclinical research, it is important to conduct studies in humans with longer treatment and greater number of volunteers to achieve better monitoring of the improvement in nerve impulse conduction in diabetic patients with or without clinical diabetic neuropathy. Our study has several limitations. Most important, there was no placebo group or control group showing the same improvement of glycemic control without sitagliptin use. Also, the number of patients and the period of observation were insufficient to assess a more consistent effect of the treatment on nerve impulse conduction. Unfortunately, this study had a small sample and was conducted over a relatively short period. Thus, studies with larger samples and longer duration are needed.

In conclusion, this study demonstrates that diabetes can affect both the central and peripheral nervous system as suggested by increases in latencies and central conduction times, meaning impaired nerve signal conduction, which improved after treatment with sitagliptin. Moreover, direct correlations between GLP-1 and some electrophysiological parameters were observed, raising the question regarding the therapeutic role of GLP-1 in subclinical neurological complications of diabetes. Research aimed at studying the GLP-1 receptors on peripheral nerves and the signaling mechanisms for this action of GLP-1 would help to resolve this question. Finally, this study is unique since the results give a glimpse of the possible use of DPP-4 inhibitors in the treatment of some neurodegenerative conditions of the peripheral nervous system, in addition to its 
already established role in the glycemic control of type 2 diabetes.

Disclosure: no potential conflict of interest relevant to this article was reported.

\section{REFERENCES}

1. Guidoni CM, Borges APS, Freitas O, Pereira LRL. Prescription patterns for diabetes mellitus and therapeutics implications: a population-based analysis. Arq Bras Endocrinol Metab. 2012;56(2):12027.

2. Yorek MA. The role of oxidative stress in diabetic vascular and neural disease. Free Radic Res. 2003;37(5):471-80.

3. American Diabetes Association. Standards of medical care in diabetes - 2010. Diabetes Care. 2010;33(Suppl 1):S11-61.

4. Legatt $A D$, Soliman E. Somatosensory evoked potentials: general principles. St. Petersburg: eMedicine Corporation; 2006.

5. Perry T, Lahiri DK, Chen D, Zhou J, Shaw KT, Egan JM, et al. A novel neurotrophic property of glucagon-like peptide 1: a promoter of nerve growth factor-mediated differentiation in PC12 cells. J Pharmacol ExpTher. 2002;300(3):958-66.

6. Perry T, Haughey NJ, Matson MP, Egan JM, Greig NH. Protection and reversal of excitotoxic neuronal damage by glucagon-like peptide-1 and exendin-4. J Pharmacol ExpTher. 2002;302(3):881-8.

7. Perry T, Holloway HW, Weerasuriya A, Mouton PR, Duffy K, Mattison JA, et al. Evidence of GLP-1-mediated neuroprotection in an animal model of pyridoxine-induced peripheral sensory neuropathy. Exp Neurol. 2007;203(2):293-301.

8. Jin HY, Liu WJ, Park JH, Baek HS, Park TS. Effect of dipeptidyl peptidase-IV (DPP-IV) inhibitor (Vildagliptin) on peripheral nerves in streptozotocin-induces diabetic rats. Arch Med Res. 2009;40(7):536-44.

9. Sakamoto Y, Oyama J, Ikeda H, Kuroki S, Gondoh S, IwamotoT, et al. Effects of sitagliptin beyond glycemic control: focus on quality of life. Cardiovasc Diabetol. 2013;12(1):35.

10. Chiappa KH. Evoked potentials in clinical medicine. New York: Lippincott Williams \& Wilkins; 1997.

11. Armitage P, Berry G. Statistical methods in medical research. Oxford: Blackwell; 1994.

12. Motulsky H. Intuitive biostatistics. Oxford: Oxford University Press; 1995.
13. VisbollT, KrarupT, Deacon CF, Madsbad S, Holst JJ. Reduced postprandial concentrations of intact biologically active glucagon-like peptide 1 in type 2 diabetic patients. Diabetes. 2001;50(3):609-13.

14. Herman GA, Bergman A, Stevens C, Kotey P, Yi B, Zhao P, et al. Effect of single oral doses of sitagliptin, a dipeptidyl peptidase-4 inhibitor, on incretin and plasma glucose levels after an oral glucose tolerance test in patients with type 2 diabetes. J Clin Endocrinol Met. 2006;91(11):4612-9.

15. Kucera P, Goldenberg Z, Varsik P, Buranova D, Traubner P. Spinal cord lesions in diabetes mellitus. Somatosensory and motor evoked potentials and spinal conduction time in diabetes mellitus. Neuro Endocrinol Lett. 2005;26(2):143-7.

16. Napoleão RM. Evoked potentials somatosensory median nerve in diabetic patients: correlations with biochemical markers. Dissertation (a Master degree in Medical Clinic), Faculty of Medicine, Federal University of Ceará, Ceará, Brazil, 2006.

17. Misulis KE. Potencial evocado de Spehlmann. Rio de Janeiro: Revinter; 2003.

18. Kikkawa Y, Kuwabara S, Misawa S, Tamura N, Kitano Y, Ogawara $\mathrm{K}$, et al. The acute effects of glycemic control on nerve conduction in human diabetics. Clin Neurophysiol. 2005;116(2):270-4.

19. Pozzessere G, Rizzo PA, Valle E, Mollica MA, Meccia A, Morano $S$, et al. Early detection of neurological involvement in IDDM and NIDDM. Multimodal evoked potentials versus metabolic control. Diabetes Care. 1998;11(6):473-80.

20. Qin X, Shen H, Liu M, Yang Q, Zheng S, Sabo M, et al. GLP-1 reduces intestinal lymph flow, triglyceride absorption, and apolipoprotein production in rats. Am J Physiol Gastrointest Liver Physiol. 2005;288(5):G943-9.

21. Wiggin TD, Sullivan KA, Pop-Busui R, Amato A, Sima AA, Feldman EL. Elevated triglycerides correlate with progression of diabetic neuropathy. Diabetes. 2009;58(7):1634-40.

22. Jolivalt CG, Fineman M, Deacon CF, Carr RD, Calcutt NA. GLP-1 signals via ERK in peripheral nerve and prevents nerve dysfunction in diabetic mice. Diabetes Obes Metab. 2011;13(11):990-1000.

23. Himeno T, Kamiya H, Naruse $K$, Harada N, Ozaki N, Seino $Y$, et al. Beneficial effects of exendin-4 on experimental polyneuropathy in diabetic mice. Diabetes. 2011;60(9):2397-406.

24. Liu WJ, Jin HY, Lee KA, Xie SH, Baek HS, ParkTS. Neuroprotective effect of the glucagon-like peptide-1 receptor agonist, synthetic exendin-4, in streptozotocin-induced diabetic rats. Br J Pharmacol. 2011;164(5):1410-20.

25. Bianchi R, Cervellini I, Porretta-Serapiglia C, Oggioni N, Burkey B, Ghezzi P, et al. J Pharmacol ExpTher. 2011;340(1):64-72. 